\title{
PERAN PERPUSTAKAAN "KERANO KUNCORO” DALAM PEMBERDAYAAN MASYARAKAT DESA SRI KUNCORO KECAMATAN PONDOK KELAPA KABUPATEN BENGKULU TENGAH
}

\author{
Merdansah, SHI.,MH \\ Email.merdansahh@gmail.com \\ PUSTAKAWAN IAIN BENGKULU
}

\begin{abstract}
Abstrak:
Tujuan dari penelitian ini adalah untuk mengetahui peran perpustakaan "Kerano Kuncoro" dalam pemberdayaan masyarakat Desa Sri Kuncoro Kecamatan Pondok Kelapa Kabupaten Bengkulu Tengah, Metode yang digunakan adalah metode kualitatif deskriptif. Penulis melakukan wawancara mendalam terhadap tujuh orang informan yang dipilih berdasarkan teknik purposive sampling. Teknik pengumpulan data dilakukan melalui observasi dan wawancara. Teknik analisis data yang digunakan adalah dengan melakukan reduksi data, penyajian data, dan penarikan kesimpulan. Penelitian ini menggunakan pendekatan triangulasi sebagai uji keabsahan data. Hasil dari penelitian ini yaitu peran perpustakaan "Kerano Kuncoro" dalam pemberdayaan masyarakat Desa Sri Kuncoro dalam meningkatkan kualitas hidupnya agar menjadi pribadi yang mandiri dan berpotensi. Pemberdayaan masyarakat yang dilakukan oleh Perpustakaan "Kerano Kuncoro" dalam bidang pendidikan, lingkungan, dan ekonomi. Masyarakat menjadi lebih giat dan termotivasi dengan adanya program pemberdayaan tersebut.
\end{abstract}

Kata Kunci : Peran, Perpustakaan "Kerano Kuncoro", Pemberdayaan Masyarakat.

\begin{abstract}
:
The purpose of this study was to determine the role of the library "Kerano Kuncoro" in empowering the community of Sri Kuncoro Village, Pondok Kelapa District, Central Bengkulu Regency. The method used was a descriptive qualitative method. The author conducted in-depth interviews with seven informants who were selected based on the purposive sampling technique. Data collection techniques were carried out through observation and interviews. The data analysis technique used is data reduction, data presentation, and conclusion drawing. This study uses a triangulation approach as a test of the validity of the data. The results of this study are the role of the "Kerano Kuncoro" library in empowering the Sri Kuncoro Village community in improving their quality of life to become independent and potential individuals. Community empowerment carried out by the "Kerano Kuncoro" library in the fields of education, environment, and economy. The community becomes more active and motivated by the empowerment program.
\end{abstract}

Keywords: Role, "Kerano Kuncoro" library, Community development.

\section{Pendahuluan}

Berdasarkan Undang-Undang No. 43 Tahun 2007 disebutkan bahwa perpustakaan berfungsi sebagai wahana pendidikan, penelitian, pelestarian, informasi dan rekreasi untuk meningkatkan kecerdasan dan keberdayaan bangsa ${ }^{1}$. Fungsi pendidikan diwujudkan dengan perpustakaan yang mampu meningkatkan kegemaran membaca penggunanya, fungsi penelitian diterapkan dengan menyediakan pelayanan untuk pemakai dalam memperoleh informasi sebagai bahan rujukan untuk kepentingan penelitian. Fungsi pelestarian yaitu sebagai tempat melestarikan bahan pustaka (bahan pustaka merupakan sumber ilmu pengetahuan, teknologi dan budaya). Fungsi informasi diterapkan dengan menyediakan sumber-sumber pustaka yang lengkap dan bermutu: Fungsi rekreasi diterapkan dengan menyediakan buku hiburan dan tata ruang yang bersifat rekreatif. Selain kelima fungsi tersebut, perpustakaan 
juga dapat berperan dalam pemeliharaan lingkungan sebagai upaya penanggulangan masalah pencemaran lingkungan. Pencemaran lingkungan merupakan salah satu masalah yang belum dapat terselesaikan dengan baik di Indonesia. Hal ini terjadi karena rendahnya kesadaran masyarakat akan kebersihan. Masih banyak sampah rumah tangga yang dibuang pada sembarang tempat meskipun sudah disediakan Tempat Pembuangan Sampah (TPS) pada setiap desa terutama sampah batok kelapa. Salah satu faktor penyebab rendahnya kesadaran masyarakat akan kebersihan adalah karena mereka tidak mampu mengakses informasi dan juga latar belakang pendidikan masyarakat yang masih rendah, akibatnya mereka kurang peduli terhadap keindahan dan kebersihan lingkungan.

Kehadiran perpustakaan desa pada dasarnya dibangun oleh rakyat dan ditujukan untuk melayani masyarakat yang bersangkutan. Perpustakaan desa mempunyai peran yang strategis bagi masyarakat desa untuk meningkatkan pengetahuan dan pengalaman ${ }^{2}$. Perpustakaan desa berperan dalam menyediakan kebutuhan informasi masyarakat, memperbaiki kesejahteraan masyarakat di sekitarnya sehingga mereka mempunyai bekal dalam pengembangan diri.

Adanya layanan perpustakaan desa masyarakat dapat menumbuhkan kesadaran akan pentingnya kebersihan lingkungan dan meningkatkan nilai guna sampah plastik yang awalnya dibuang di sembarang tempat, selanjutnya bisa menjadi bahan tukar dalam peminjaman bahan pustaka di perpustakaan. Keberadaan perpustakaan desa di tengah masyarakat jika disadari lebih mendalam, tidak lain adalah salah satu upaya pemberdayaan masyarakat.

${ }^{1}$ Undang-undang No. 43 Tahun 2007

2Sutarno NS, Membina Perpustakaan Desa. (Jakarta: Sagung Seto, 2008: 139)

${ }^{3}$ Romadhan, Kades Desa Sri Kuncoro Kecamatan pondok kelapa Kabupaten Bengkulu Tengah, 19 September 2021

${ }^{4}$ Surat Keputusan Menteri dalam Negeri dan Otonomi Daerah Nomor 3 Tahun 2001
Seperti yang dilakukan oleh Perpustakaan Kerano Kuncoro desa Sri Kuncoro dalam menyediakan layanan peminjaman buku berbayar dengan sampah plastik. Berdasarkan uraian tersebut, maka masalah yang akan dikaji dalam penelitian ini adalah bagaimana peran Perpustakaan Kerano Kuncoro dalam pemberdayaan masyarakat Desa Sri Kuncoro Kecamatan Pondok Kelapa Kabupaten Bengkulu Tengah Provinsi Bengkulu?

Adapun tujuan penelitian untuk mengetahui peran Perpustakaan Kerano Kuncoro dalam pemberdayaan masyarakat Desa Sri Kuncoro Kecamatan Pondok Kelapa Kabupaten Bengkulu Tengah. Penelitian ini diharapkan dapat bermanfaat baik secara teoritis maupun praktis sebagai berikut:

\section{Manfaat Teoritis}

Memberikan sumbangan keilmuan bagi perkembangan ilmu perpustakaan dan informasi terutama dalam kaitannya dengan peran perpustakaan Kerano Kuncoro dalam pemberdayaan masyarakat.

\section{Manfaat Praktis}

Penelitian ini diharapkan dapat memberikan informasi pada pihak perpustakaan desa Kerano Kuncoro dan lembaga pemberdayaan masyarakat sebagai bahan pertimbangan dalam mengambil kebijakan dan evaluasi mengenai peran perpustakaan Kerano Kuncoro dalam pemberdayaan masyarakat Desa Sri Kuncoro.

\section{Landasan Teori}

Penduduk Indonesia mayoritas hidup di daerah pedesaan. Hal ini menunjukan potensi besar pada bidang sumber daya manusia. Jika potensi ini dimanfaatkan dengan baik, maka desa akan berkembang dan memiliki fungsi bagi daerah lain maupun kotanya sendiri. Salah satu sarana pemberdayaan dan pembinaan potensi ini adalah pendidikan dengan segala perangkatnya, diantaranya yaitu perpustakaan. Pemerintah melalui surat keputusan Menteri dalam Negeri dan Oto- 
nomi Daerah Nomor 3 Tahun 2001 tentang pembentukan perpustakaan desa, telah dijelaskan mengenai pentingnya perpustakaan desa untuk mencerdaskan dan memberdayakan masyarakat serta menunjang pelaksanaan pendidikan nasional perlu dikembangkan sebagai salah satu sumber belajar bagi masyarakat dalam bentuk perpustakaan desa. Dengan bangganya di Provinsi Bengkulu telah terbit Peraturan Gubernur Bengkulu No 30 Tahun 2019 Tentang Transformasi Perpustakaan Berbasis Inklusi Sosial diharapkan dengan adanya peraturan ini dapat meningkatkan mutu Perpustakaan Desa/Kelurahan agar dapat terwujudnya masyarakat gemar membaca Di Propinsi Bengkulu.

\section{Profile Desa Sri Kuncoro}

Desa Sri Kuncoro terletak di dalam wilayah Kecamatan Pondok Kelapa Kabupaten Tengah Provinsi Bengkulu yang berbatasan dengan :

- Sebelah utara : berbatasan dengan Desa Panca Mukti dan Kecamatan Pondok Kelapa

- Sebelah timur : berbatasan dengan Desa Linggar Galing dan Tahura Kecamatan Pondok Kubang

- Sebelah selatan : berbatasan dengan Kelurahan Pematang Gubernur Kecamatan Muara Bangka Hulu

- Sebelah barat : berbatasan dengan Desa Pekik Nyaring dan Srikaton dan KecamatanPondok Kelapa.

Desa Sri Kuncoro adalah desa ex Transmigrasi yang dipimpin oleh seorang Kepala Desa yang bernama Romadhan dengan jumlah penduduk sebanyak 2089 jiwa. Desa Sri Kuncoro mempunyai perpustakaan desa yang di beri nama Perpustakaan Kerano Kuncoro yang dipimpin oleh

\footnotetext{
5Sutarno, Ibid 2006: 217

${ }^{6}$ Murniaty. "Sistem Pelayanan Perpustakaan Desa/Kelurahan dan Perpustakaan Sekolah Sumatera Utara: 2013

${ }^{7}$ Gill, Philip. The Public Library Service: IFLA/UNESCO Guidelines for Development. Netherlands: IFLA and Institution Publication, 2001:87

${ }^{8}$ Mardikanto, Totok dan Poerwoko Soebiato. Pemberdayaan Masyarakat dalam Perspektif Kebijakan Publik. Bandung: Alfabeta. 2013, 215.
}

seorang kepala perpustakaan desa yaitu Ibu Yuli Puspita dan 10 orang pengelola dengan jumlah anggota 1070 anggota serta jumlah judul buku berjumlah 3027 dan 5800 eksamplar. $^{3}$

\section{Perpustakaan Desa}

Perpustakaan desa adalah wadah penyedia bahan bacaan sebagai salah satu sumber belajar bagi masyarakat dalam rangka mencerdaskan dan memberdayakan masyarakat, serta menunjang pelaksanaan pendidikan nasional ${ }^{4}$ (Surat Keputusan Menteri dalam Negeri dan Otonomi Daerah Nomor 3 Tahun 2001). Sementara itu menurut Sutarno NS, perpustakaan desa adalah lembaga layanan publik yang berada di desa. Sebuah unit layanan yang dikembangkan dari, oleh dan untuk masyarakat tersebut.

Perpustakaan desa mempunyai peran yang strategis bagi masyarakat desa untuk meningkatkan pengetahuan dan pengalaman. Terbentuknya perpustakaan desa adalah untuk sarana pelayanan kepada masyarakat sebagai penyedia sumber informasi yang cepat, tepat dan murah untuk menunjang program wajib belajar dan program pendidikan keterampilan masyarakat lainnya, serta membantu warga untuk mengembangkan kemampuan yang dimilikinya sehingga dapat bermanfaat bagi masyarakat di sekitarnya, sejauh kemampuan tersebut dapat dikembangkan dengan bantuan bahan pustaka. Namun secara umum menurut Sutarno NS ada lima kegiatan perpustakaan, yaitu ${ }^{5}$ :

1) Pengadaan Koleksi

Pengadaan koleksi merupakan proses awal dalam mengisi perpustakaan dengan sumbersumber informasi. Adapun hal pokok yang harus ditetapkan berkaitan dengan koleksi seperti penyusunan rencana pengadaan

\footnotetext{
${ }^{9}$ Ibid, 2013:105

${ }^{10}$ Suharyanti. Pengantar Dasar Ilmu Perpustakaan. Surakarta: LPP UNS dan UNS Press, 2008: 11

${ }^{11}$ Sutarno NS, 2006: 33

${ }^{12} \mathrm{Ibid}, 2006: 121$

${ }^{13}$ Moleong, Lexy J. Metode Penelitian Kualitatif. Bandung: Remaja Rosdakarya. 2010:11
} 
koleksi, menghimpun alat seleksi koleksi, survei bahan pustaka, dan menyeleksi bahan pustaka.

2) Pengolahan

Pengolahan adalah pekerjaan yang diawali sejak koleksi diterima di perpustakaan sampai dengan penempatan di rak yang telah disediakan.

3) Layanan

Layanan adalah kegiatan memberi bantuan kepada pengguna dalam memenuhi kebutuhan hidup sesuai yang diharapkannya. Di sebuah perpustakaan tentunya berbeda dengan layanan pada kegiatan kemasyarakatan yang lain seperti layanan kesehatan dan layanan keagamaan. Prinsip-prinsip yang sama atau berdekatan, yaitu:

a) Sesuai dengan kebutuhan masyarakat yang dilayani.

b) Dilaksanakan secara cepat, tepat, dan akurat.

c) Menciptakan kesan yang menarik, sehingga menimbulkan kepuasan masyarakat.

Secara khusus Murniaty menjelaskan jenis layanan yang biasanya ada di perpustakaan desa seperti layanan sirkulasi, layanan referensi, layanan koleksi deposit, layanan multimedia, dan layanan perpustakaan keliling ${ }^{6}$.

4) Administrasi Perpustakaan

Adapun kegiatan yang dimaksud administrasi perpustakaan disini adalah kegiatan yang berada di sekretariat, kegiatan ini merupakan penunjang kegiatan pokok. Kegiatan ini antara lain mengenai ketatausahaan, kepegawaian keuangan, dan kerumahtanggaan.

5) Sosialisasi

Istilah sosialisasi atau pemasyarakatan bagi

${ }^{14}$ Yin, Robert K. 2013. Studi Kasus, Desain \& Metode. Jakarta: Raja Grafindo Persada. 2013:192

${ }^{15}$ Sugiyono. Metode Penelitian Kuantitatif, Kualitatif dan R\&D. Bandung: Alfabeta,2008:227

${ }^{16}$ Mukhtar. Metode Praktis Penelitian Deskriptif Kualitatif. Jakarta: Referensi. 2013:119

${ }^{17}$ Sugiyono, Ibid 2008:247-249

${ }^{18}$ Sugiyono. ibid,2008:252 perpustakaan selalu dikaitkan dengan upaya promosi perpustakaan, menjaring minat dan respon masyarakat dengan memberikan sesuatu yang berguna, mengembangkan kerjasama dengan berbagai pihak yang terkait, serta mengembangkan upaya mendekatkan dan membangun jembatan antara perpustakaan dan masyarakat pengguna.

Sosialisasi perpustakaan dilakukan dalam rangka membangun citra positif perpustakaan. Dengan memaksimalkan lima hal tersebut di perpustakaan, maka sebuah perpustakaan dapat memenuhi kebutuhan dan selera pengunjung serta dapat memberikan sesuatu yang bermanfaat dan nilai tambah kepada masyarakat. Nilai yang terkandung dalam Public Library Manifesto, yaitu perpustakaan sebagai gerbang menuju pengetahuan untuk menyediakan kondisi awal bagi perorangan atau kelompok dalam melakukan kegiatan belajar seumur hidup, pengambilan keputusan mandiri serta pembangunan budaya. ${ }^{7}$ Nilai ini selalu ada sebagai acuan yang melandasi berdirinya sebuah perpustakaan. Perpustakaan merupakan pusat lokal informasi, membuat semua jenis pengetahuan dan informasi dapat tersedia untuk para pengguna. Kegiatan perpustakaan yang bersifat aktif menjadikan masyarakat mudah memperoleh dan mencari informasi, keaktifan ini mendorong perpustakaan dalam memberikan layanan dan fasilitas yang baik atas dasar kesetaraan akses untuk semua pengguna tanpa memandang usia, ras, jenis kelamin, agama, dan bahasa.

Pada prinsipnya layanan dan fasilitas yang ada di perpustakaan harus terorganisir dengan baik dan dilakukan secara professional, sehingga dapat mendorong masyarakat dalam meningkatkan kemampuan mencari dan memperoleh informasi. Kemampuan tersebut diharapkan dapat menambah modal pengetahuan yang berguna bagi masyarakat, modal tersebuat nantinya dapat dimanfaatkan untuk meningkatkan kesejahteraan 
dalam bidang ekonomi, budaya, dan pendidikan. Masyarakat yang memiliki akses informasi lebih mudah untuk beradaptasi serta memanfaatkan lingkungan yang ada, informasi sebagai modal bisa ditindak lanjuti dengan sebuah tindakan. Melalui tindakan inilah masyarakat nantinya dapat memperoleh keuntungan langsung baik berupa materi maupun immateri, dengan begitu secara perlahan masyarakat telah melakukan proses pemberdayaan melalui kegiatan perpustakaan.

\section{Konsep Pemberdayaan Masyarakat}

Pemberdayaan masyarakat sebagai sebuah strategi sekarang telah banyak diterima, bahkan telah berkembang dalam berbagai literatur di dunia barat. Menurut Totok Mardikanto, pemberdayaan masyarakat adalah sebuah konsep pembangunan ekonomi yang merangkum nilainilai sosial ${ }^{8}$. Secara konseptual pemberdayaan masyarakat adalah upaya untuk meningkatkan harkat dan martabat masyarakat dalam kondisi yang sekarang tidak mampu untuk melepaskan diri dari perangkat kemiskinan dan keterbelakangan, dengan kata lain memberdayakan adalah memampukan dan memandirikan masyarakat.

Dari pengertian diatas penulis dapat menyimpulkan bahwa pemberdayaan masyarakat adalah upaya menjadikan masyarakat menjadi pribadi yang mandiri supaya dapat memenuhi kebutuhan hidupnya, serta dapat menggali potensi yang ada dalam masyarakat dengan berbagai keterampilan yang ada dalam diri manusia menjadi masyarakat yang produktif. Adapun beberapa hal yang harus diperhatikan agar proses pemberdayaan masyarakat dapat berjalan secara maksimal adalah sebagai berikut:

\section{a. Prinsip-prinsip pemberdayaan masyarakat}

Mathews dalam Mardikanto, mengatakan bahwa prinsip adalah suatu pernyataan tentang

${ }^{19}$ Moleong, Lexy J. Metode Penelitian Kualitatif. Bandung: Remaja Rosdakarya. 2010:330-331

${ }^{20}$ Yuli Pustpita, Wawancara dengan Kepala Perpustakaan "Kerano Kuncoro" desa Sri Kuncoro Kecamatan Pondok Kelapa Kabupaten Bengkulu Tengah, 22 Agustus 2021

${ }^{21}$ Romadhan, Wawancara dengan Kepala Desa Sri Kuncoro Kecamatan Pondok Kelapa Kabupaten Bengkulu Tengah, 22 Agustus 2021 kebijaksanaan yang dijadikan pedoman dalam pengambilan keputusan dan melaksanakan kegiatan secara konsisten ${ }^{9}$. Dengan demikian, prinsip dapat dijadikan sebagai landasan pokok yang benar bagi pelaksanaan kegiatan yang dilaksanakan.

\section{b. Tujuan Pemberdayaan Masyarakat}

Tujuan pemberdayaan meliputi beragam upaya perbaikan pendidikan, perbaikan aksesibilitas, perbaikan tindakan, perbaikan lembaga, perbaikan usaha, perbaikan pendapatan, perbaikan lingkungan, perbaikan kehidupan, perbaikan masyarakat. Tujuan dari adanya program pemberdayaan masyarakat yang telah dilakukan oleh suatu pihak tertentu merupakan bentuk perbaikan, perbaikan dalam arti memperbaiki keadaan dari sebelumnya tidak mampu menjadi mampu agar harapan yang telah direncanakan dapat terwujud.

\section{c. Indikator Pemberdayaan Masyarakat}

Pengertian pemberdayaan adalah proses pemberian dan optimasi daya yang dimiliki dan dimanfaatkan oleh masyarakat. Baik daya dalam pengertian kemampuan dan keberanian maupun daya dalam arti kekuasaan atau posisi-tawar. Dalam praktek pemberdayaan masyarakat yang dilakukan oleh banyak pihak, seringkali terbatas pada pemberdayaan ekonomi dalam rangka pengentasan kemiskinan atau penanggulangan kemiskinan. Karena itu, kegiatan pemberdayaan masyarakat selalu dilakukan dalam bentuk pengembangan kegiatan produktif untuk peningkatan pendapatan.

Konsep pemberdayaan bukanlah sekedar pelatihan, income generating atau advokasi. Pemberdayaan masyarakat harus dilakukan secara terintegrasi mencakup empat kelompok kegiatan yaitu: bina manusia, bina usaha, bina lingkungan, dan bina. Indikator dalam pemberdayaan masyarakat memang sudah seharusnya dilakukan secara terintegrasi mencakup empat kelompok kegiatan tersebut. Dalam kegiatan 
pemberdayaan masyarakat, indikator pemberdayaan harus diperhatikan dengan baik agar bermanfaat terhadap berbagai bidang yang ada. Dengan demikian perpustakaan dan pemberdayaan sebagai upaya untuk menuangkan peran dan nilai-nilai perpustakaan dalam kehidupan bermasyarakat, melalui inovasi pemberdayaan terutama masyarakat desa atau kelompok yang perlu diberdayakan.

\section{Pemberdayaan Masyarakat melalui Per- pustakaan}

Pemberdayaan merupakan upaya untuk menjadikan masyarakat berdaya, memiliki potensi, dan tidak tertinggal, ketertinggalan suatu masyarakat biasanya disebabkan oleh faktor ketidaktahuan, kemiskinan dan penyakit. Untuk mengatasi ketertinggalan ini, tujuan utama yang dicapai yaitu dengan meningkatkan pengetahuan masyarakat agar tercipta manusia yang memiliki sumber daya unggul. Upaya-upaya pemberdayaan masyarakat ini bertujuan untuk mendidik dan membantu diri mereka sendiri untuk meningkatkan pengetahuan masyarakat merupakan tujuan dari pendidikan nasional dalam upaya mencerdaskan kehidupan bangsa. Salah satu cara dalam meningkatkan kecerdasan bangsa dengan meningkatkan kualitas pendidikan yang dapat dilakukan melalui perpustakaan karena perpustakaan merupakan institusi yang memiliki peran dalam menyediakan informasi bagi masyarakat. Menurut Suharyanti sebuah perpustakaan harus dapat menunjang keberhasilan program pendidikan terutama pendidikan diluar sekolah, bagi orang-orang yang sudah tidak duduk lagi di bangku sekolah. Pemberdayaan melalui perpustakaan ini berhubungan dengan bidang pendidikan. Perpustakaan adalah sebuah lembaga yang menjabarkan ilmu pengetahuan dan hasil-hasil pemikiran manusia dengan tidak henti-hentinya, dan merupakan tempat belajar seumur hidup ${ }^{10}$.

Salah satu institusi yang memegang peran dalam dunia pendidikan, maka usaha pember- dayaan masyarakat pun dapat dilakukan melalui perpustakaan. Melalui perpustakaan masyarakat tidak hanya dapat memperoleh ilmu pengetahuan dari bahan pustaka yang dilayankan, tetapi juga mengembangkan bakat dan potensi yang mereka miliki dengan memanfaatkan fasilitas dan layanan yang ada di perpustakaan. Maksud pembentukan perpustakaan bagi masyarakat menurut Sutarno NS adalah sebagai berikut:

1. Menjadi tempat mengumpulkan atau menghimpun informasi, dalam arti aktif perpustakaan terus-menerus mengumpulkan sebanyak mungkin sumber informasi untuk dikoleksi.

2. Sebagai tempat mengolah atau memproses semua bahan pustaka dengan metode dan sistem tertentu seperti registrasi, klasifikasi, katalogisasi, dan kelengkapan lain agar mudah digunakan.

3. Menjadi tempat penyimpanan dan pemeliharaan, artinya ada kegiatan untuk mengatur, memelihara, dan merawat agar koleksi rapi, terawatt serta mudah diakses.

4. Sebagai salah satu pusat informasi, sumber belajar, penelitian, dan rekreasi. Memberi layanan kepada pemakai seperti membaca, meminjam, meneliti dengan cara yang cepat, tepat, dan mudah.

5. Membangun tempat informasi yang lengkap up-to-date bagi pengembangan pengetahuan, keterampilan, dan perilaku.

6. Merupakan agen pengubah dan agen kebudayaan dari masa lalu, sekaran, dan masa depan. Kemajuan perpustakaan menjadi kebanggaan, dan simbol peradaban kehidupan umat manusia. ${ }^{11}$

Pemberdayaan masyarakat melalui perpustakaan dapat dilakukan, yaitu dengan meningkatkan minat terhadap buku atau bacaan. Minat baca yang tinggi menjadikan seseorang dapat memperoleh informasi dari bacaan yang dibacanya dalam rangka meningkatkan pengetahuan. 
Minat baca dapat ditumbuhkan dengan menanamkan kebiasaan membaca kepada seseorang, yang nantinya diharapkan lama-kelamaan akan terbiasa dan menjadi budaya baca bagi dirinya sendiri. Dengan timbulnya budaya baca pada seseorang maka akan timbul rasa keingintahuan akan pengetahuan yang dia miliki. Rasa keingintahuan akan pengetahuan dapat diperoleh dari koleksi buku yang tersedia pada sebuah perpustakaan. Untuk mengatasi masalah rendahnya minat baca masyarakat Indonesia, perlu usaha yang lebih. Menurut Sutarno NS untuk meningkatkan minat baca sebagai upaya pemberdayaan masyarakat dapat dilakukan melalui perpustakaan, diantaranya dengan program berbasis buku, program peningkatan kemampuan membaca dengan memberikan bimbingan membaca yang baik, lomba baca, bedah buku, bercerita (story telling), dan buku gambar. ${ }^{12}$

\section{Metode Penelitian}

Penelitian mengenai peran perpustakaan dalam pemberdayaan masyarakat ini menggunakan desain penelitian kualitatif. Penelitian kualitatif berusaha memahami fenomena yang dialami oleh subjek penelitian seperti perilaku, persepsi, motivasi, dan tindakan. Jenis penelitian yang digunakan adalah jenis penelitian deskriptif. Penelitian deskriptif merupakan jenis penelitian yang memberikan data berupa kata-kata atau wawancara dari informan yang diteliti, dan semua itu dikumpulkan berkemungkinan menjadi kunci terhadap apa yang telah diteliti ${ }^{13}$. Dengan penelitian ini akan memberikan gambaran secara cermat mengenai peran Perpustakaan Kerano Kuncoro dalam pemberdayaan masyarakat Desa Sri Kuncoro Kecamatan Pondok Kelapa Kabupaten Bengkulu Tengah. Subjek dalam penelitian ini adalah masyarakat Desa Sri Kuncoro yang menggunakan layanan perpustakaan serta yang terlibat dalam kepengurusan sedangkan objeknya adalah perpustakaan Kerano Kuncoro dalam pemberdayaan masyarakat.

Adapun cara pemilihan informan dengan teknik purposive sampling. Kemudian peneliti menyeleksi dan mengambil tujuh orang yang terdiri dari kepala perpustakaan dan dua petugas perpustakaan untuk dijadikan informan tambahan mengenai keberadaan data, serta empat pemustaka untuk dijadikan informan inti dalam penelitian. Pertimbangan pemilihan informan didasarkan pada kriteria informan yang terlibat dalam kegiatan pemberdayaan di Perpustakaan Kerano Kuncoro Desa Sri Kuncoro, mengetahui program kerja yang telah atau sedang dilakukan, berperan aktif dalam kegiatan yang diadakan. Pada penelitian ini informan ditulis menggunakan nama lengkap dan tidak disamarkan, karena topik yang diangkat dalam penelitian bukan mengandung kontroversial ${ }^{14}$.

Penelitian ini menggunakan data primer dan sekunder. Penelitian ini mendapatkan data primer melalui wawancara dan observasi. Adapun data sekunder melalui dokumen yang dimiliki Perpustakaan Kerano Kuncoro desa Sri Kuncoro meliputi brosur dan dokumen lain berupa sejarah perpustakaan, struktur organisasi, statistik pengunjung, dan daftar koleksi perpustakaan Kerano Kuncoro Desa Sri Kuncoro.

a) Observasi

Penulis menggunakan observasi partisipatif pasif. Observasi partisipatif pasif yaitu peneliti datang ke tempat kegiatan orang yang diamati, tetapi tidak ikut terlibat dalam kegiatan tersebut. ${ }^{15}$ Observasi yang dilakukan dalam penelitian ini dengan datang ke kantor Perpustakaan Kerano Kuncoro desa Sri Kuncoro untuk mengamati secara langsung bagaimana peran perpustakaan Kerano Kuncoro desa Sri Kuncoro dalam pemberdayaan masyarakat Desa Sri Kuncoro Kecamatan Pondok Kelapa Kabupaten Bengkulu Tengah.

b) Wawancara

Wawancara menggunakan daftar pertanyaan semi-terstruktur tujuan wawancara dilakukan untuk memperoleh informasi yang mendalam dan maksimal mengenai peran 
Perpustakaan Kerano Kuncoro dalam pemberdayaan masyarakat Desa Sri Kuncoro sehingga dapat menjawab semua persoalan yang menjadi masalah dalam penelitian ini. Proses penelitian dengan menggunakan alat bantu perekam sebagai media pendukung, atas sepengetahuan informan.

c) Dokumentasi

Dokumentasi adalah data pendukung yang dikumpulkan sebagai penguat data observasi dan wawancara, biasanya berbentuk tulisan, gambar atau digital ${ }^{16}$. Dokumen yang digunakan yaitu dokumen administrasi dan artikel yang dimuat dalam media massa mengenai peran Perpustakaan Kerano Kuncoro dalam pemeberdayaan Masyarakat Desa Sri Kuncoro. Kegiatan dalam analisis data kualitatif, yaitu reduksi data, penyajian (data display), penarikan kesimpulan, berikut penjelasannya:

1) Reduksi Data

Data yang telah direduksi akan memberikan gambaran yang lebih jelas, dan mempermudah penelitian untuk melakukan pengumpulan data selanjutnya ${ }^{17}$ Analisis data pada penelitian ini, dimulai dengan membuat transkrip wawancara dengan memutar kembali rekaman hasil wawancara oleh informan mengenai kegiatan pemberdayaan masyarakat yang dilakukan oleh perpustakaan Kerano Kuncoro desa Sri Kuncoro, kemudian dipilah berdasarkan informasi yang relevan mengenai tujuan penelitian.

2) Penyajian Data

Penyajian data yang paling sering digunakan dalam penelitian kualitatif adalah

${ }^{22}$ Alin, Wawancara dengan Sekretaris Desa Sri Kuncoro Kecamatan Pondok Kelapa Kabupaten Bengkulu Tengah, 22 Agustus 2021

${ }^{23}$ Nenti Septa Eriyanti, Wawancara dengan Sekretaris Perpustakaan Desa Kerano kuncoro, 22 Agustus 2021

${ }^{24} \mathrm{Fevti}$ Priyati, Wawancara dengan Kepala Urusan tata usaha dan umum Desa Sri Kuncoro Kecamatan Pondok Kelapa Kabupaten Bengkulu Tengah, 22 Agustus 2021 melalui teks yang bersifat naratif. Data yang disajikan berbentuk narasi atau serangkaian kata yang telah disusun berdasarkan hasil wawancara dari informan.

3) Penarikan Kesimpulan

Langkah ketiga dalam analisis data kualitatif menurut Miles and Huberman dalam Sugiyono, yaitu penarikan simpulan dan verifikasi. Penarikan simpulan dilakukan setelah semua data direduksi dan disajikan dengan rapi. Tujuan penarikan kesimpulan untuk menjawab rumusan masalah yang dirumuskan sejak awal. Uji keabsahan data menggunakan pendekatan triangulasi ${ }^{18}$. Triangulasi menurut Moleong adalah teknik pemeriksaan keabsahan data yang memanfaatkan sesuatu lain di luar data itu, untuk keperluan pengecekan atau sebagai perbandingan terhadap data itu, triangulasi yang digunakan adalah triangulasi dengan sumber ${ }^{19}$. Menurut Patton dalam triangulasi dengan sumber berarti membandingkan dan mengecek balik derajat kepercayaan suatu informasi yang diperoleh melalui waktu dan alat yang berbeda dalam metode kualitatif. Peneliti melakukan uji keabsahan data dengan cara pengecekan hasil observasi dan wawancara yang didapat dari informan dengan berbagai perspektif dan keadaan yang berbeda, kemudian dengan dokumentasi.

\section{Pembahasan}

Hasil wawancara yang dilakukan penulis terhadap masyarakat Desa Sri Kuncoro dalam pemberdayaan yang dilakukan oleh pengurus perpustakaan Kerano Kuncoro dapat dilihat dari latar belakang berdirinya perpustakaan, peran layanan perpustakaan, bentuk pemberdayaan dalam berbagai bidang serta kegiatan-kegiatan yang diadakan, dan hasil yang diperoleh dari adanya proses pemberdayaan tersebut. ${ }^{20}$ 


\section{Latar Belakang Berdirinya Perpustakaan "Kerano Kuncoro" Desa Sri Kuncoro}

Pengagas utama hadirnya layanan perpustakaan yang ramah lingkungan adalah dari Romadhan selaku Kepala Desa setempat. Hal yang mendasari Romadhan dalam usaha memberikan konsep layanan peminjaman buku berbayar dengan sampah plastik adalah bentuk keprihatinannya terhadap pencemaran lingkungan serta minat baca masyarakat yang semakin rendah dikarenakan dengan adanya gadget yang saat ini tersebar luas hampir setiap orang punya. Gagasan awal ini bermula dari adanya kondisi lingkungan yang tidak bersih, karena masih banyak sampah plastik berserakan di jalan padahal sudah disediakan tempat pembuangan sampah pada setiap tempat-tempat tertentu, sehingga Romadhan ingin menggabungkan antara perpustakaan dan bank sampah. Kehadiran Perpustakaan Kerano Kuncoro desa Sri Kuncoro ini diharapkan dapat menjadi fasilitas untuk masyarakat dalam meningkatkan kepribadian yang gemar membaca serta peduli lingkungan. ${ }^{21}$

Tujuan berdirinya Perpustakaan Kerano Kuncoro untuk memberikan layanan dalam rangka memenuhi kebutuhan warga yang berkaitan dengan informasi, ilmu pengetahuan, pendidikan, dan rekreasi kepada semua lapisan masyarakat tanpa keterkecualian. Kemudian dikembangkan dengan perpanduan konsep perpustakaan dan bank sampah sebagai wujud dari bentuk keprihatinannya terhadap masalah pencemaran lingkungan serta menurunnya minat baca masyarakat. Adanya layanan perpustakaan berbayar sampah plastik dan batok kelapa ini diharapkan dapat meningkatkan minat baca masyarakat dan peduli terhadap kebersihan serta keindahan lingkungan.

${ }^{25}$ Sugito, Wawancara dengan Kepala Dusun II Desa Sri kuncoro Kecamatan Pondok Kelapa Kabupaten Bengkulu Tengah, 22 Agustus 2021

${ }^{26}$ Yuli Puspita, Wawancara dengan Kepala Seksi Pelayanan Desa Sri kuncoro Kecamatan Pondok Kelapa Kabupaten Bengkulu Tengah, 22 Agustus 2021

\section{Peran Layanan dalam Pemberdayaan Ma- syarakat}

Salah satu tujuan dari adanya layanan perpustakaan Kerano Kuncoro adalah pemberdayaan masyarakat desa Sri Kuncoro yaitu membantu pemerintah dalam mewujudkan masyarakat yang mandiri serta berpotensi untuk memenuhi kebutuhan hidupnya. Berdasarkan tujuan ini maka Perpustakaan Kerano Kuncoro memiliki peran dalam pemberdayaan masyarakat. Peran Perpustakaan Kerano Kuncoro desa Sri Kuncoro sendiri hanya sebatas sebagai pendukung dan pembantu masyarakat dalam mengali potensi yang sebenarnya dimiliki.

Perpustakaan Kerano Kuncoro desa Sri Kuncoro tidak bertanggung jawab secara penuh atas pengembangan bakat masyarakat, hal ini dikarenakan keterbatasan yang dimiliki perpustakaan desa Sri Kuncoro. Perpustakaan Kerano Kuncoro desa Sri Kuncoro hanya berusaha menyediakan layanan yang berupa fasilitas serta sarana-prasarana pendukung kegiatan pemberdayaan dalam rangka menjadikan masyarakat yang mandiri dan berpotensi. ${ }^{22}$

\section{Bentuk Pemberdayaan Masyarakat}

Pemberdayaan masyarakat di Perpustakaan Kerano Kuncoro desa Sri Kuncoro berbasiskan pendidikan, perpustakaan berusaha memberikan kecakapan-kecakapan dasar pada masyarakat agar nantinya masyarakat dapat mengembangkannya dari ilmu yang telah diperoleh di perpustakaan Kerano Kuncoro desa Sri Kuncoro, selain mengenai masalah pendidikan masyarakat, Perpustakaan Kerano Kuncoro desa Sri Kuncoro juga melakukan pemberdayaan masyarakat pada bidang lingkungan dan ekonomi. Adapun kegiatan-kegiatan yang dilakukan pada setiap bidangnya sebagai berikut:

\section{a) Bidang Pendidikan}

Kegiatan yang dilakukan perpustakaan Kerano Kuncoro Desa Sri Kuncoro dalam bidang pendidikan dengan melatih dan membiasakan masyarakat untuk membaca. Adapun cara yang 
dilakukan dengan menyediakan berbagai jenis bahan bacaan pada layanan sirkulasi dan melakukan perpustakaan keliling secara sederhana untuk menjangkau masyarakat yang tidak dapat datang langsung ke kantor Perpustakaan Kerano Kuncoro Desa Sri Kuncoro.

\section{b) Bidang Lingkungan}

Pemberdayaan masyarakat dalam bidang lingkungan yang dilakukan oleh Perpustakaan Kerano Kuncoro desa Sri Kuncoro dengan menerapkan program peminjaman buku berbayar dengan sampah plastik dan batok kelapa. Kegiatan pemberdayaan lingkungan yang diadakan oleh perpustakaan Kerano Kuncoro desa Sri Kuncoro tujuannya untuk menjaga keindahan dan keasrian alam, dengan membiasakan masyarakat Kerano Kuncoro desa Sri Kuncoro agar tidak membuang sampah pada sembarang tempat dan lebih mempertimbangkan nilai guna sampah plastik dan batok kelapa.

\section{c) Bidang Ekonomi}

Kegiatan pada bidang ekonomi yaitu dengan mengadakan pelatihan keterampilan mengolah sampah plastik menjadi berbagai kerajinan tangan yang dapat dimanfaatkan untuk kehidupan sehari-hari. Dengan adanya pemberdayaan yang dilakukan pada bidang ekonomi masyarakat Desa Sri Kuncoro diharapkan dapat mengembangkan keterampilan yang didapat dari hasil pelatihan, sehingga masyarakat dapat membuka peluang usaha sendiri dan mendapat keuntungan dari hasil penjualan. ${ }^{23}$

Dari 3 bidang pemberdayaan yang dilakukan oleh perpustakaan Kerano Kuncoro desa Sri Kuncoro merupakan bentuk dari pemberdayaan potensi masyarakat melalui berbagai kegiatan. Namun secara garis besar bentuk pemberdayaan pada perpustakaan Kerano Kuncoro Desa Sri Kuncoro menitikberatkan pada pendekatan pendidikan.

\section{Dampak Program Pemberdayaan Masyarakat}

Dampak dari adanya program pemberdayaan masyarakat yang diadakan di perpustakaan Kerano Kuncoro desa Sri Kuncoro ini bersifat positif. Hal ini dapat dilihat dari hasil pemberdayaan yang dilakukan di Perpustakaan Kerano Kuncoro desa Sri Kuncoro pada masing-masing bidang pemberdayaan sudah mulai terlihat, yaitu meningkatnya kepedulian dan perhatian masyarakat akan kebersihan lingkungan, bertambahnya jumlah pengunjung perpustakaan, dan keterampilan berinovasi dengan sampah plastik dan batok kelapa yang hasilnya dapat digunakan sendiri maupun untuk dijual. ${ }^{24}$

\section{Tanggapan Masyarakat terhadap Perpusta- kaan Kerano Kuncoro desa Sri Kuncoro}

Adapun tanggapan masyarakat Desa Sri Kuncoro terhadap keberadaan perpustakaan Kerano Kuncoro desa Sri Kuncoro memang membawa dampak perubahan pada masyarakat Desa Sri Kuncoro. Hal ini dapat dilihat dari faktor koleksi yang tersedia untuk meningkatkan minat baca masyarakat, dengan adanya layanan yang berbasis lingkungan masyarakat juga dapat termotivasi dan menyadari akan pentingnya nilai guna sampah plastik untuk kepentingan pendidikan. Masyarakat pun menyadari akan pentingnya keberadaan Perpustakaan Kerano Kuncoro desa Sri Kuncoro karena banyak manfaat yang diperolehnya seperti dapat digunakan untuk mengisi waktu luang dengan kegiatan yang lebih bermanfaat yaitu dengan membaca. Karena ilmu yang didapat dengan membaca bisa disebarluaskan dan diterapkan dalam kehidupan sehari-hari. Keterampilan dalam mendaur ulang bahan bekas juga dapat diperoleh masyarakat dengan adanya pelatihan yang diadakan setiap tahunnya. Selain itu dengan adanya layanan perpustakaan yang peduli lingkungan dapat menumbuhkan kesadaran masyarakat mengenai hal kebersihan. ${ }^{25}$

\section{Respon Masyarakat Mengenai Pemberdayaan}

Respon masyarakat Desa Sri Kuncoro terhadap pemberdayaan yang dilakukan oleh Per- 
pustakaan Kerano Kuncoro cukup baik. Hal ini terlihat dari antusias mereka dalam berpatisipasi di setiap kegiatan yang diadakan oleh Perpustakaan tersebut :26

\section{a) Bidang Pendidikan}

Pemberdayaan pada bidang pendidikan yang dilakukan oleh Perpustakaan Kerano Kuncoro desa Sri Kuncoro adalah untuk meningkatkan minat baca masyarakat. Dimana kebiasaan membaca itu harus menjadi kebutuhan pokok dalam masyarakat. Menanggapi hal tersebut masyarakat setuju dan merespon baik adanya program yang dilakukan oleh Perpustakaan Kerano Kuncoro. Masyarakat berpendapat memang sudah seharusnya kebiasaan membaca itu ditanamkan pada masyarakat terlebih anak-anak di usia dini.

\section{b) Bidang Lingkungan}

Pemberdayaan pada bidang lingkungan yang dilakukan oleh Perpustakaan Kerano Kuncoro desa Sri Kuncoro dengan menyediakan layanan peminjaman buku berbayar sampah plastik dan batok kelapa. Penerapan sistem peminjaman yang dilakukan oleh Perpustakaan Kerano Kuncoro desa Sri Kuncoro, mendapatkan respon yang baik dari masyarakat. Hal itu terlihat dari antusias masyarakat yang semula tidak peduli terhadap sampah plastik dan batok kelapa sekarang mereka lebih giat untuk mengumpulkannya. Masyarakat juga bangga terhadap program pemberdayaan masyarakat yang dilakukan oleh Perpustakaan Keranao Kuncoro tersebut, karena lambat laun pastinya akan menjadikan lingkungan Desa Sri Kuncoro yang asri dan indah.

\section{c) Bidang Ekonomi}

Pemberdayaan yang dilakukan oleh Perpustakaan desa Kerano Kuncoro dalam bidang ekonomi dengan memberikan pelatihan dalam bentuk keterampilan mengolah sampah plastik menjadi barang serbaguna. Masyarakat Desa Sri Kuncoro sangat antusias dalam hal ini, bahkan dengan adanya kegiatan ini dapat dijadikan daya tarik tersendiri untuk para remaja perempuan dan ibu-ibu berkunjung ke perpustakaan. Kegiatan ini selain digunakan untuk memanfaatkan sampah plastik yang sudah terkumpul dari hasil peminjaman buku, juga untuk menumbuhkan daya inovatif dan kreativitas pada setiap individunya agar mereka mau mengembangkan potensi yang sebenarnya dimiliki. Dengan adanya pemberdayaan pada bidang ekonomi yang dilakukan oleh Perpustakaan Kerano Kuncoro melalui pelatihan kemudian mengadakan kompetisi memang membawa perubahan pada masyarakat Desa Sri Kuncoro.

\section{Kesimpulan dan Saran}

Berdasarkan temuan penulis tentang peran Perpustakaan Kerano Kuncoro dalam pemberdayaan masyarakat Desa Sri Kuncoro Kecamatan Pondok Kelapa Kabupaten Bengkulu Tengah diperoleh kesimpulan sebagai berikut:

1) Peran Perpustakaan Kerano Kuncoro desa Sri Kuncoro dalam pemberdayaan masyarakat adalah sebagai pembantu dan pendukung masyarakat dalam meningkatkan kualitas hidupnya agar menjadi pribadi yang mandiri dan berpotensi. Dalam menjalankan perannya sebagai pembantu dan pendukung masyarakat, Perpustakaan Kerano Kuncoro desa Sri Kuncoro memerlukan petugas yang dapat bertanggung jawab penuh atas kegiatan yang ada.

2) Perpustakaan Kerano Kuncoro desa Sri Kuncoro dalam pemberdayaan masyarakat memiliki peran dalam tiga bidang yaitu pendidikan, lingkungan, dan ekonomi. Kegiatan untuk peran pendidikan dengan melatih dan membiasakan masyarakat untuk gemar membaca, untuk peran lingkungan dengan menerapkan program pinjam buku berbayar sampah plastik dan batok kelapa, sedangkan peran ekonomi dengan mengadakan pelatihan keterampilan daur ulang sampah plastik menjadi barang serba guna. Kegiatan-kegiatan tersebut dapat berjalan dengan baik apabila didukung oleh sarana dan prasarana perpustakaan Kerano Kuncoro desa Sri Kuncoro yang memadai.

3) Masyarakat Desa Sri Kuncoro menjadi lebih 
giat dan termotivasi dengan adanya program pemberdayaan yang dilakukan perpustakaan Kerano Kuncoro antusias masyarakat semakin tinggi dalam memanfaatkan waktu luang untuk membaca dan peduli terhadap kebersihan lingkungan. Sebagian dari mereka juga dapat menghasilkan keterampilan tangan untuk dijual.

\section{Daftar Pustaka}

Gill, Philip. 2001. The Public Library Service: IFLA/UNESCO Guidelines for Development. Netherlands: IFLA and Institution Publication.

Keputusan Menteri Dalam Negeri dan Otonomi Daerah Nomor 3 Tahun 2001 tentang perpustakaan desa/kelurahan. 2001. Jakarta: Menteri Dalam Negeri dan Otonomi Daerah RI.

Mardikanto, Totok dan Poerwoko Soebiato. 2013. Pemberdayaan Masyarakat dalam Perspektif Kebijakan Publik. Bandung: Alfabeta.

Moleong, Lexy J. 2010. Metode Penelitian Kualitatif. Bandung: Remaja Rosdakarya.

Mukhtar. 2013. Metode Praktis Penelitian Deskriptif Kualitatif. Jakarta: Referensi.

Murniaty. 2013. "Sistem Pelayanan Perpustakaan Desa/ Kelurahan dan Perpustakaan Sekolah". Pelatihan pengelolaan perpustakaan desa/kelurahan dan perpustakaan sekolah. Sumatera Utara: Kantor Perpustakaan dan Arsip Daerah Tarutung.

Perpustakaan Nasional RI. 2001. Pedoman Penyelenggaraan Perpustakaan Desa. Jakarta: Perpustakaan Nasional RI.

Romadhan, Wawancara Kepala desa Sri Kuncoro Kecamatan Pondok Kelapa Kabupaten Bengkulu Tengah, 2021
Sugiyono. 2008. Metode Penelitian Kuantitatif, Kualitatif dan R\&D. Bandung: Alfabeta.

Suharyanti. 2008. Pengantar Dasar Ilmu Perpustakaan. Surakarta: LPP UNS dan UNS Press

Sutarno NS. 2006. Perpustakaan dan Masyarakat. Jakarta: Sagung Seto. . 2006. Manajemen Perpustakaan: Suatu Pendekatan Praktik. Jakarta: Sagung Seto.

2008. Membina Perpustakaan Desa. Jakarta: Sagung Seto.

Undang-undang Republik Indonesia Nomor 43 Tahun 2007 tentang Perpustakaan. 2007. Jakarta: Perpustakaan Nasional RI.

Yin, Robert K. 2013. Studi Kasus, Desain \& Metode. Jakarta: Raja Grafindo Persada.

Yuli Pustpita, wawancara Kepala Perpustakaan "Kerano Kuncoro" desa Sri Kuncoro Kecamatan Pondok Kelapa Kabupaten Bengkulu Tengah, 2021

Alin, dengan Sekretaris Desa Sri Kuncoro Kecamatan Pondok Kelapa Kabupaten Bengkulu Tengah, 22 Agustus 2021

Nenti Septa Eriyanti, Wawancara dengan Sekretaris Perpustakaan Desa Kerano kuncoro, 22 Agustus 2021

Fevti Priyati, Wawancara dengan Kepala Urusan tata usaha dan umum Desa Sri Kuncoro Kecamatan Pondok Kelapa Kabupaten Bengkulu Tengah, 22 Agustus 2021

Sugito, Wawancara dengan Kepala Dusun II Desa Sri kuncoro Kecamatan Pondok Kelapa Kabupaten Bengkulu Tengah, 22 Agustus 2021

Yuli Puspita, Wawancara dengan Kepala Seksi Pelayanan Desa Sri kuncoro Kecamatan Pondok Kelapa Kabupaten Bengkulu Tengah, 22 Agustus 2021 